Génét. Sél. Evol., 1988, 20 (2), 247-254

\title{
Note
}

\section{Identification of the two common alleles of the bovine $k$-casein locus by the RFLP technique, using the enzyme Hind III}

\author{
H. LEVÉZIEL, Liliane MÉTÉNIER, Marie-Françoise MAHÉ, J. CHOPLAIN, \\ J.-P. FURET, G. PABCEUF, J.-C. MERCIER and F. GROSCLAUDE \\ Institut National de la Recherche Agronomique, Laboratoire de Génétique Biochimique, \\ Centre de Recherches de Jouy-en-Josas, 78350 Jouy-en-Josas, France
}

\begin{abstract}
Summary
As could be predicted from a comparison of the cDNA sequences established by STEWART $e t$ al. (1984) and GORODETSKIY \& KALEDIN (1987) the two common alleles of the bovine $\kappa$-casein locus, $\mathrm{k}-\mathrm{Cn}^{A}$ and $\mathrm{k}-\mathrm{Cn}^{B}$, can be identified by the restriction fragment length polymorphism (RFLP) technique using either Hind III or Taq I. The latter endonuclease also detects a polymorphism of the DNA strand carrying the allele $\kappa-C n^{A}$. However, for determination of both alleles, the use of Hind III is preferable because, according to the data of the above authors, the RFLP detected by that enzyme is specific for the amino-acid substitution responsible for the difference in charge of the two $\kappa$-casein variants. When DNA is prepared from blood leucocytes, the occurrence of chimaerism in twins may cause difficulties in interpretation.
\end{abstract}

Key words : cattle, к-casein, genetic variants, RFLP.

\section{Résumé}

Identification des deux allèles communs du locus de la caséine $\mathrm{\kappa}$-bovine par un polymorphisme de longueur des fragments de restriction obtenus avec l'enzyme Hind III

Comme on pouvait le prédire par comparaison des séquences d'ADN complémentaire établies par Stewart et al. (1984) et GorodeTsKiY \& Kaledin (1987), les deux allèles communs du locus de la caséine $\kappa$ bovine, $\kappa-C n^{A}$ et $\kappa-C n^{B}$, sont identifiables par un polymorphisme de longueur des fragments de restriction, en utilisant soit Hind III, soit Taq I. Cette dernière endonucléase révèle aussi un polymorphisme du brin d'ADN portant l'allèle $\kappa^{-}-C^{A}$. Pour la détermination des deux allèles, l'utilisation de Hind III est préférable car, d'après les données des auteurs ci-dessus, le polymorphisme détecté par cet enzyme est spécifique de la substitution d'acides aminés responsable de la différence de charge entre les deux variants de la caséine $\kappa$. Si l'ADN a été préparé à partir de leucocytes du sang, l'existence d'un chimérisme chez les jumeaux peut causer des difficultés d'interprétation.

Mots clés : bovins, caséine $\mathrm{\kappa}$, variants génétiques, polymorphisme de longueur des fragments de restriction. 
Bovine $\kappa$-casein, of which the primary structure (169 amino-acid residues) was determined by Mercier et al. (1973), is polymorphic in all breeds, with two common variants, $\kappa-\mathrm{CnA}$ and $\kappa-\mathrm{CnB}$, detectable by alkaline gel electrophoresis. The difference in electrophoretic mobility between those variants results from the substitution $148 \mathrm{Asp}$ $(\kappa-\mathrm{CnA}) \rightarrow$ Ala ( $\mathrm{k}-\mathrm{CnB})$ (Grosclaude et al., 1972). In addition this substitution was, in the small number of samples analysed, associated with a second substitution, $136 \mathrm{Thr}$ $(\kappa-\mathrm{CnA}) \rightarrow$ Ile $(\kappa-\mathrm{CnB})$, which has no effect on the net charge of the protein.

It may be concluded from several concordant studies that, as compared to variant $\kappa-\mathrm{CnA}$, variant $\kappa-\mathrm{CnB}$ gives the milk better cheese making properties, mainly shorter rennet clotting time and rate of firmness, firmer curd, and, for certain types of cheese, higher yielding capacity (see review by Grosclaude, 1988). This would recommend a selection for allele $\kappa-C n^{B}$ in dairy breeds. Unfortunately the possibility of determining the genotype of bulls at locus $\mathrm{\kappa}-\mathrm{Cn}$ by testing progeny milk samples takes about five years. The detection of alleles $\kappa-C n^{A}$ and $\kappa-C n^{B}$ at birth, by DNA analysis, could thus be of a real practical interest.

A comparison of the cDNA sequences of the alleles $\kappa-C n^{A}$ (STEWART et al., 1984) and $\kappa-C n^{B}$ (GoRodetskiY \& KALEDIN, 1987) reveals that the mutation $\mathrm{A} \rightarrow \mathrm{C}$, responsible for the substitution $148 \mathrm{Asp} \rightarrow \mathrm{Ala}$, induces a Hind III site in the allele $\kappa-C n^{B}$ (fig. 1), and that the mutation $\mathrm{C} \rightarrow \mathrm{T}$ responsible for the substitution $136 \mathrm{Thr} \rightarrow \mathrm{Ile}$ induces a Taq I site in the same allele. Moreover, no other Hind III or Taq I site exists within these two published cDNA sequences. Those observations suggested a possible identification of alleles $\kappa-C n^{A}$ and $\kappa-C n^{B}$ by the technique of restriction fragment length polymorphism (RFLP) using enzymes Hind III and Taq I.

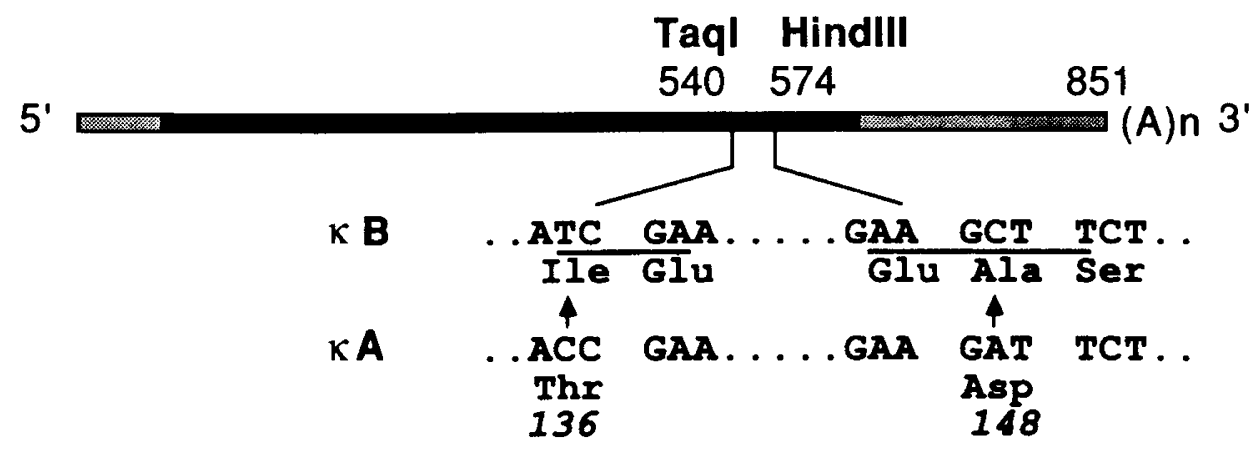

\section{Ovine $\kappa$-casein cDNA probe}

FIg. 1

Nucleotide sequences of bovine $\mathrm{\kappa}$-casein $A$ and $B \mathrm{cDNAs}$ in the region encoding the amino acids differentiating the genetic variants $A$ and $B$.

This schematic representation is based on the nucleotide sequences of $\kappa$-casein cDNA $A$ and $B$ (STEWART et al., 1984 ; GoRODETSKIY \& KALEDIN, 1987). The amino acid substitutions occur at positions 136 and 148 of mature $\mathrm{\kappa}$-casein (GROSCLAUDE et al., 1972). The relevant mutations lead to the appearance of unique Taq I and Hind III restriction sites in $\mathrm{\kappa}$-casein $B$ cDNA. Gray and black upper boxes represent the $5^{\prime} / 3^{\prime}$ non coding regions and the reading frame of the full-length $c D N A$, respectively. Numbers indicate positions of Taq I and Hind III sites downstream from the 5' end. The lower box represents the partial ovine $\mathrm{k}$-casein cDNA used to probe bovine genomic DNA. 


\section{Materials and methods}

\section{A. Animals}

Forty-five Normande or Holstein cows from the INRA experimental herd at Le Pin-au-Haras, in Normandy, comprising the female progeny of 25 different bulls, were investigated (table 1). Only 14 cows formed dam-daughter pairs : 6 dams and their 8 daughters, including 2 half-sisters and 2 twins.

\section{TABLE 1}

Distribution of investigated cows by breed and $\mathrm{\kappa}$-casein genotype

\begin{tabular}{l|c|c|c}
\hline \multirow{2}{*}{ Genotype } & \multicolumn{2}{|c|}{ Breed } & \multirow{2}{*}{} \\
\cline { 2 - 4 } & Normande & Holstein & \\
\hline \multirow{2}{*}{$A / A^{(*)}$} & 1 & 13 & 14 \\
$A / B$ & 3 & 10 & 13 \\
$B / B$ & 15 & 3 & 18 \\
\hline & 19 & 26 & 45 \\
\hline
\end{tabular}

$\left({ }^{*}\right)$ For $A / A$, read $\kappa-C n^{A / A}$, etc.

\section{B. Preparation and phenotype analysis of whole casein}

Bovine whole casein was prepared by isoelectric precipitation of individual skimmilk samples and analyzed by starch gel electrophoresis at $\mathrm{pH} 8.6$, as previously described (Grosclaude et al., 1965).

\section{C. к-casein cDNA probe}

A $648 \mathrm{bp}$ long ovine $\kappa$-casein cDNA starting at the 211th nucleotide of the fulllength counterpart, at the level of the 47th codon (FURET et al., 1988, submitted), was radiolabelled with $\left(\alpha^{32} \mathrm{P}\right) \mathrm{dCTP}$ to a specific activity of $10^{9} \mathrm{dpm} / \mu \mathrm{g}$, using the «multiprime DNA labelling system RPN $1601 »$ of Amersham.

\section{Preparation and Southern blot analysis of genomic DNA}

Southern blot analysis was performed according to the 10th HLA workshop's reference protocol (MARCADET et al., 1988). Briefly, $20 \mathrm{ml}$ blood samples were collected in EDTA, and after elimination of red cells by lysis, the leucocytes were incubated overnight at $42{ }^{\circ} \mathrm{C}$ in lysis buffer containing proteinase $\mathrm{K}$. Genomic DNA was then isolated by two phenol-chloroform-isoamyl alcohol extractions, then precipitated by isopropanol with $\mathrm{NaCl}(60 \mathrm{mM})$, and after three washes with $70 \%$ ethanol, resuspended in Tris-EDTA $(1 \mathrm{mM} ; 0.1 \mathrm{mM} ; \mathrm{pH} 7.6)$. The endonucleases Hind III and Taq I were used as specified by the manufacturer (Boehringer), but spermidine $(2 \mathrm{mM})$ was added to Hind III digestions and the enzymes were always added in three stages, to 
give a total of $5 \mathrm{U} / \mu \mathrm{g}$ DNA. After $43 \mathrm{~h}$ electrophoresis $(0.9 \%$ agarose ; $25 \mathrm{~V})$, and alkaline transfer $(0.4 \mathrm{M} \mathrm{NaOH}, 18 \mathrm{~h}$ at room temperature) onto nylon membrane (Biotrace), the blots were incubated for $5 \mathrm{~h}$ at $42{ }^{\circ} \mathrm{C}$ in individual plastic bags containing $30 \mathrm{ml}$ prehybridizing solution : $50 \%$ formamide, $5 \%$ dextran sulfate, $0.1 \%$ denhardt, 5 X SSPE $\left(0.9 \mathrm{M} \mathrm{NaCl} ; 50 \mathrm{mM} \mathrm{NaH} \mathrm{PO}_{4} ; 5\right.$ mM EDTA ; pH 7.7), $1 \%$ SDS and $200 \mu \mathrm{g}$ salmon sperm DNA/ml. Hybridization was carried out in $20 \mathrm{ml}$ of the above (fresh) solution containing $25 \mathrm{ng}$ of the radiolabelled cDNA probe $\left(40 \mathrm{~h} ; 42^{\circ} \mathrm{C}\right)$. Membranes were washed twice with $2 \mathrm{X}$ SSPE (room temperature ; $5 \mathrm{~min}$ ), once with $2 \times \mathrm{SSPE}, 0.5 \% \operatorname{SDS}\left(65^{\circ} \mathrm{C} ; 15 \mathrm{~min}\right)$, and finally once with $0.5 \mathrm{X} \operatorname{SSPE}\left(65^{\circ} \mathrm{C}\right.$; $15 \mathrm{~min}$ ) before autoradiography (X-OMAT-AR films; Kodak). Sizes of restriction fragments were estimated according to SchAfFer \& SEderoff (1981) by running both " Hind III/Smal" and "Kpnl/BstEll" phage $\lambda$ DNA fragments in parallel, as well as the standard BRL " $5615 \mathrm{SA} / \mathrm{SB}$ ” molecular size marker (data not shown).

\section{Results}

Figure 2 shows examples of patterns found after hybridization of Hind III digests. Besides a $0.8 \mathrm{~kb}$ fragment present in all samples, a polymorphism made up of fragments of approximately $2.2,3.3$ and $5.5 \mathrm{~kb}$ may be observed. A comparison of this polymorphism with the genotypes deduced from electrophoresis of the protein indicated

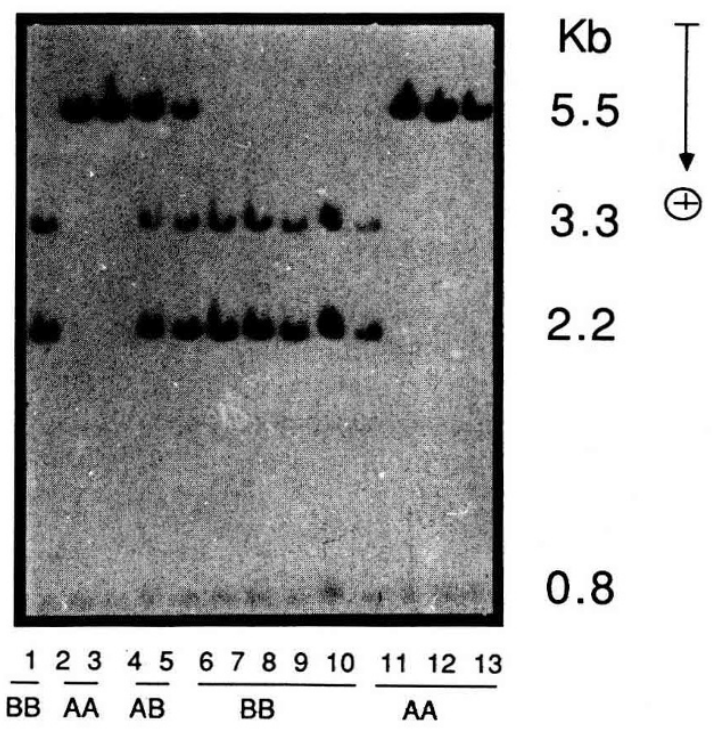

Fig. 2

Identification of $\mathrm{k}$-casein genotypes by Southern blot hybridization of Hind III digests of bovine genomic DNA. One fragment of $0.8 \mathrm{~kb}$ occurs in all samples, whereas the other fragments are polymorphic. The restriction patterns suggest that the 2.2 and $3.3 \mathrm{~kb}$ fragments characterizing allele $\mathrm{\kappa}-\mathrm{Cn}^{\mathrm{B}}$ arise from the cleavage of the $5.5 \mathrm{~kb}$ fragment occurring only in allele $\mathrm{\kappa}-\mathrm{Cn}^{\mathrm{A}}$. These $R F L P$ phenotypes match the $\mathrm{k}$-casein genotypes (lower line) deduced from the electrophoretic analysis of whole casein samples obtained from the same cows, with one exception, not shown. 
that the genotype $\mathrm{k}-\mathrm{Cn} \mathrm{n}^{\mathrm{A} / \mathrm{A}}$ gave only the $5.5 \mathrm{~kb}$ fragment, while the genotype $\mathrm{\kappa}-\mathrm{Cn} \mathrm{n}^{B / b}$ gave both the 2.2 and $3.3 \mathrm{~kb}$ fragments, a result compatible with the existence of an additional Hind III site in allele $\kappa-\mathrm{Cn}^{B}$. As expected, the heterozygous genotype, $\kappa-C n^{A / B}$, gave all three fragments, except in one case (Holstein cow 042, a twin) for which the DNA pattern was that otherwise associated with the $\mathrm{k}-\mathrm{Cn} n^{B / B}$ genotype.
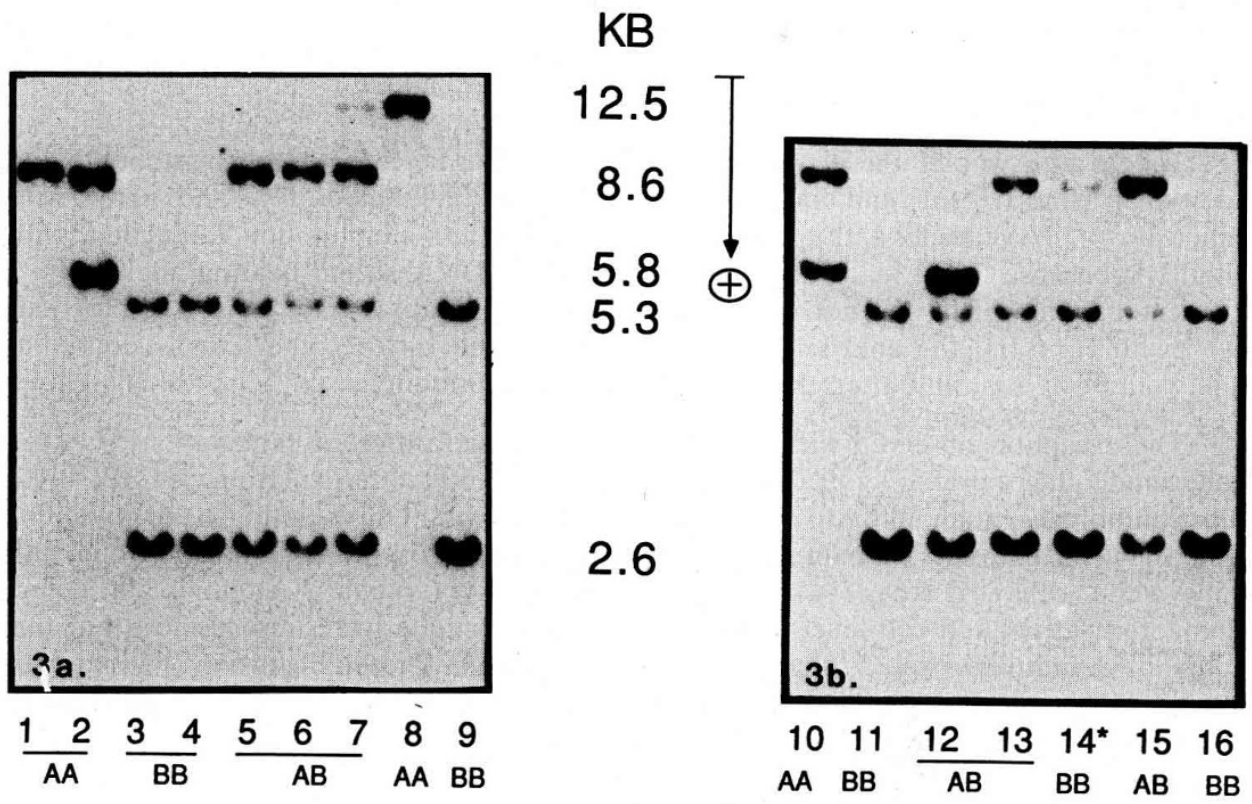

Fig. 3

Identification of $\mathrm{K}$-casein genotypes by Southern blot hybridization of Taq I digests of bovine genomic DNA. Animals of genotype $\mathrm{K}-\mathrm{Cn}^{\mathrm{B} \mathrm{B}}$, as deduced from the phenotypic analysis of both $\mathrm{K}$-casein and Hind III RFLP, are characterized by the occurrence of two Taq I fragments of 2.6 and $5.3 \mathrm{~kb}$ (lanes 3, 4, 9, 11, 14* and 16). Those of genotype $\mathrm{k}-\mathrm{Cn}^{\mathrm{A} / \mathrm{A}}$ fall into three subgroups on the basis of the observed Taq I patterns since they contain either a unique 12.5 (lane 8 ) or $8.6 \mathrm{~kb}$ (lane 1) fragment or both 8.6 and $5.8 \mathrm{~kb}$ fragments (lanes 2 and 10). Heterozygous $\mathrm{k}-\mathrm{Cn}^{\mathrm{A}} \mathrm{B}$ cows show comparable heterogenous $A$ patterns : occurrence of a unique 8.6 (lanes 5-7, 13 and 15) or $5.8 \mathrm{~kb}$ fragment (lane 12 ). Lane $14^{*}$ refers to a chimaeric cow (see text). Fig. $3 \mathrm{~b}$ represents a partial view of the gel, but all animals lacked the $12.5 \mathrm{~kb}$ fragment.

Figure 3 shows examples of patterns found after hybridization of Taq I digests. With this enzyme, $\kappa-\mathrm{Cn}^{B / B}$ homozygotes all produced two fragments of approximately 2.6 and $5.3 \mathrm{~kb}$. Furthermore, 9 out of the $14 \mathrm{k}-C n^{A / A}$ homozygotes produced one fragment of about $8.6 \mathrm{~kb}$ (fig. 3a, sample 1). Those results were in accordance with the existence of an additional Taq I site in allele $\kappa-C n^{B}$. However, two further patterns were observed among the 5 remaining $\mathrm{K}-\mathrm{Cn}^{\mathrm{A} / \mathrm{A}}$ homozygotes with fragments of about 5.8 and $12.5 \mathrm{~kb}$ (fig. $3 a$ and $b$ samples $\mathrm{n}^{\circ} 2,8$ and 10). As a whole, those results suggested that three different Taq I fragments of approximately 5.8, 8.6 and $12.5 \mathrm{~kb}$ respectively could represent allele $\kappa-C n^{A}$. Again with the same exception (cow 042), the patterns observed with $\kappa-C n^{A / B}$ heterozygotes did not disagree with the above hypothesis : in 10 out of the 13 individuals, allele $\mathrm{k}-\mathrm{Cn} \mathrm{n}^{A}$ was represented by the $8.6 \mathrm{~kb}$ band, in two 
individuals, by the $5.8 \mathrm{~kb}$ band, the DNA pattern of the heterozygous cow 042 again being that otherwise associated with the $\kappa_{-} C n^{B / B}$ genotype (fig. $3 b, n^{\circ} 16$ ). Note finally that sample $n^{\circ} 14$ (fig. 3b) was from a twin of genotype $\kappa-C n^{B / B}$ and the existence of a faint $8.6 \mathrm{~kb}$ band is very likely due to a chimaerism of white cells.

\section{Discussion}

Taken as a whole, these observations are in accordance with the existence of an additional Hind III site and an additional Taq I site in allele $\kappa-C n^{B}$ and agree with expectations. Nevertheless, the patterns obtained are less simple with Taq I than with Hind III, because Taq I leads to a subdivision of the DNA strand bearing allele $\kappa-C n^{A}$, a phenomenon which was not a priori totally unexpected. In fact it is possible that, even with Hind III, the analysis of more samples might disclose other subdivisions, but this would not basically alter the conclusions of the present work.

The exception observed with cow 042 may have two different explanations. On the one hand, the existence of a second $\kappa-\mathrm{CnA}$ variant, differing from $\kappa-\mathrm{CnB}$ by a substitution other than $148 \mathrm{Asp} \rightarrow$ Ala would be possible. On the other hand, twin 042 may show an extreme chimaerism of white cells, being of genotype $\kappa-C n^{A / B}$ but with only white cells of type $\kappa \cdot C n^{B / B}$ transmitted by her co-twin. Attempts to detect chimaerism at the red cell level by the absorption technique were unsuccessful, but this does not definitively exclude the phenomenon. Conclusive results can only be expected from a biochemical analysis of the $\kappa-\mathrm{CnA}$ variant of cow 042 , which is in progress in our laboratory.

In conclusion, the two common alleles of the bovine $\mathrm{k}$-casein locus, $\kappa-\mathrm{Cn}^{A}$ and $\mathrm{\kappa}$ $C n^{B}$, can be detected at the DNA level by the RFLP technique, using either Hind III of Taq I. However the use of Hind III is preferable because the DNA polymorphism produced by that enzyme is specific to the amino acid substitution responsible for the difference in charge of the two casein variants, $148 \mathrm{Asp}(\kappa-\mathrm{CnA}) \rightarrow$ Ala $(\kappa-\mathrm{CnB})$. It is not known whether the second amino acid substitution, $136 \mathrm{Thr}(\kappa-\mathrm{CnA}) \rightarrow \mathrm{Ile}$ $(\kappa-\mathrm{CnB})$, whose specific mutation is detected by Taq $\mathrm{I}$, is always associated with the former, because it was only analysed in a few casein samples. Secondarily the possible existence of two $\kappa$-casein variants of type $A$ is under study. Finally, when using DNA prepared from blood leucocytes, attention should be paid to possible difficulties in interpretation, due to the occurrence of chimaerism in dizygotic twins.

Received December 7, 1987. Accepted January 26, 1988.

\section{Acknowledgements}

We thank A. Muller and Y. Gallard, INRA, Domaine du Pin-au-Haras, 61310 Exmes, for providing the milk and blood samples. 


\section{References}

GoRodetskiY S.I., Kaledin A.S., 1987. Nucleotide sequence analysis of cow $\mathrm{k}$-casein cDNA. Genetika, 23, 596-604.

Grosclaude F., 1988. Le polymorphisme génétique des principales lactoprotéines bovines. Relations avec la quantité, la composition et les aptitudes fromagères du lait. INRA Prod. Anim., $1(1), 5-17$.

Grosclaude F., Pujolle J., Garnier L., Ribadeau-Dumas B., 1965. Déterminisme génétique des caséines $\kappa$ du lait de vache ; étroite liaison du locus $\kappa-C n$ avec les loci $\alpha_{\mathrm{S} 1}-C n$ et $\beta-C n$. C.R. Acad. Sci., Paris, 261, 5229-5232.

Grosclaude F., Mahé M.-F., Mercier J.-C., Ribadeau-Dumas B., 1972. Localisation des substitutions d'acides aminés différenciant les variants $\mathrm{A}$ et $\mathrm{B}$ de la caséine $\kappa$ bovine. Ann. Génét. Sél. Anim., 4, 515-521.

Marcadet A., O'Connel P., Cohen D., 1988. Southern reference protocole. In : Dupont B. (ed.), Histocompatibility testing, 1987, Munksgaard, Copenhagen (in press).

Mercier J.-C., Brignon G., Ribadeau-Dumas B., 1973. Structure primaire de la caséine кB bovine. Séquence complète. Eur. J. Biochem., 35, 222-235.

SCHAFFER H.E., SEDERofF R.R., 1981. Improved estimation of DNA fragment lengths from agarose gels. Anal. Biochem., 115, 113-122.

Stewart A.F., Willis I.M., MacKinlay A.G., 1984. Nucleotide sequences of bovine $\alpha_{\mathrm{s} 1}$ and к-casein cDNAs. Nucleic Acids Res., 12, 3895-3907. 